\title{
Typical demand trends in the youth labor market in the Republic of Crimea
}

\author{
Elena Polishchuk*, Olga Pochupailo \\ V.I. Vernadsky Crimean Federal University, 95007 Simferopol, Russia
}

\begin{abstract}
Monitoring of the main component of the labor market of the Republic of Crimea - the demand for labor force, taking into account representatives of young people of all age groups was conducted. The possibility of objective needs of employers in young specialists was determined on the basis of a questionnaire survey of heads of organizations (enterprises) in the region, the purpose of which was to identify information about the opinions and expectations of employers regarding the quality of training of young specialists. The structure and volume of the sample were determined as sufficient and representative to assess the situation in the Republic of Crimea as a whole. The questionnaires were processed using a computer program for statistical data processing - SPSS 13.0 for Windows. It was found that in modern conditions there is a significant need for the development of labor potential of young people and its use in the interests of innovative development of the Republic. The basic measures, the implementation of which will stabilize the situation with young personnel for all priority economic activities of the republic, have been proposed.
\end{abstract}

\section{Introduction}

The transformations taking place recently in the socio-economic development significantly affect both the labor market as a whole and its significant segment - the youth labor market. The situation which is taking shape on this market shows the high level of youth unemployment, first, because of the mismatch between trained specialists in the context of training areas (specialties) and the basic requirements of employers; second, because even having received education, young people most often lack practical skills, business communication skills, are not familiar with the ways of finding their first job or, on the contrary, have inflated requirements for a potential job and for wages accordingly; third, an insufficiently formed system of partnerships in the process of promoting youth employment, as well as a range of other problems, which contributes significantly to increasing disparities in the labor market.

The formation of a modern portrait of the youth of the Republic of Crimea in the new socio-economic conditions is impossible without close interaction between the institution of education and the institute of the labor market, because interacting they pursue one of the important objectives, which is expressed in increasing the welfare of each member of

\footnotetext{
* Corresponding author: pea.znu@mail.ru
} 
society, through the satisfaction of personal needs, implementation of educational services and effective employment $[1,2]$.

In this regard, it is objectively necessary to study the demand in the youth labor market in order to eliminate existing imbalances, rationally use the labor force and expand the sphere of productive employment of young people, allowing to increase the efficiency of the use of their labor potential.

In recent years in the domestic and world science there has been a significant increase in the interest of researchers in the study of the regular transformations of demand in the labor market under the conditions of efficient distribution of labor resources.

For example, Professor Bylkov V., representing Baikal State University, has studied not only cause-and-effect relations between the substances of the category of demand in the labor market, but also revealed its parameters and main varieties. He proved that taking into account the processes of formation of demand for labor and the life cycle of the development of organizational units will allow to objectively determine the varieties and factors of the impact of demand for labor [3].

The researcher also established that the change in demand for labor force at the level of economic entities occurs under the influence of external and internal factors on the capacity of demand for labor force and the structure of vacancies. He distinguished the stages of demand formation at the level of economic entities, positioning of vacancies in the system of labor market infrastructure, replacement of a particular workplace [4].

In turn, scientists (Budnik E., Bavykina E.) from Biysk Technological Institute (branch of Polzunov Altai State Technical University) investigated the problems of young specialists' employment in Altai Krai labor market, to specify which they conducted a sociological survey of employers to identify their expectations regarding personal competences of youth representatives, suggested an action plan to contribute to the solution of young citizens' employment problems [5].

Researchers from Moscow Technological University (Prokopov N., Antonyuk S.) together with scientists from Moscow State University of Education (Ivanov S., Ivanova D.) studied trends in the development of social and labor relations in the youth labor market in conditions of financial and economic instability. They determined the key directions of demand formation for graduates in the regional labor market. They paid attention to the requirements of modern employers to young specialists, the development of measures to manage employment, adaptation of young people in the labor market [6].

The author from Siberian Federal University (Khokhlova M.) described the main competences of competitiveness of a young specialist according to the results of sociological research conducted among employers and graduates of educational organizations of Krasnoyarsk [7].

Representatives of Don State Technical University (Meskhi B.) and Southern Federal University (Filonenko V., Skachkova L., Filonenko J.) evaluated employers' perception of competitiveness factors of graduates of educational organizations, employers' opinions on professional and personal qualities of graduates, and employers' preferences in the recruitment of young specialists [8].

In turn, Protsch P., representing the Berlin Social Science Center, assessed the degree of employers' preferences in the German labor market, taking into account the gender aspect in the process of hiring young people [9].

A joint study by representatives of Hunan University ( $\mathrm{Yu} \mathrm{He}$, Hangtian $\mathrm{Xu}$ ) and the Center of Policy Studies, Victoria University (Peng X.) on the level of education, supply and demand in the labor market allowed the authors to assess the activities that contribute to balancing supply and demand in the labor market for young people [10].

Researchers from South Africa, representing the University of Johannesburg (Patel L., Graham L., Chowa G.), proved the effectiveness of certain groups of non-economic 
indicators affecting the employment of young people of certain age groups, which should be considered when forecasting supply and demand in the South African labor market [11].

Representatives of Kazan Federal University (Kolesnikova J., Kamasheva A., Fakhrutdinova A.) conducted a study with content analysis to identify the main preferences of employers and young specialists with higher education in the labor market of the Republic of Tatarstan). They found out that employers are primarily interested in graduates of faculties of personnel management and economics [12].

At the same time, scientists representing the University of Economics in Bratislava (Gontkovičová B., Mihalčová B., Pružinský M.), considered unemployment among young people as one of the key problems in the labor market of EU countries, which makes a significant contribution to increasing imbalances that require prompt elimination [13].

A joint study by representatives of Humboldt University Berlin and RWI (Kluve J., Stöterau J.), International Labor Organization (Puerto S., Weidenkaff F.), World Bank (Robalino D., Romero J., F. Rother), University of Oxford (Witte M.) allowed analyzing the main youth employment programs affecting their labor market position. The authors found that the investigated youth employment programs have the most impact on the situation of youth and labor markets of developing countries [14].

Joint work related to the study of unemployment among young people in some European Union countries was presented by researchers of the University of Molise (Refrigeri L.) and the University of Macerata (Aleandri G.), who proposed key schemes of educational and professional orientation and adaptation, contributing to the reduction of unemployment and the effective process of employment of young people of different age groups [15].

Acknowledging the high scientific significance of the studies of the above-mentioned scientists, it should be noted that a number of characteristic trends in the demand on the labor market of individual regions requires its development.

\section{Methodology}

To identify the specific features of the youth labor market, we monitored one of the main components of the labor market - the demand for labor force, taking into account representatives of young citizens of all age groups.

Identification of the objective needs of employers in young specialists was determined on the basis of a questionnaire survey of heads of organizations (enterprises) in the region, the purpose of which was to find information about the opinions and expectations of employers regarding the quality of training of young professionals in modern conditions.

During the monitoring, conducted from February 2021 to May 2021, the heads of small, medium and large organizations (enterprises) of the main forms of ownership (state, municipal, private), operating in municipalities (urban districts, municipal regions) and settlements (urban, rural) of the Crimean region were interviewed.

The number of respondents included in the sample population and guaranteeing reliable results was 2003 people (10\% of the general population, which does not exceed 2500 respondents, provided that the size of the general population is 5000 or more units).

Calculation of the sample was carried out according to two main parameters of the quota: the area of activity (type of economic activity) of the organization and the size of the organization (enterprise) taking into account the average number of employees (up to 100 people, up to 250 people, over 250 people).

The questionnaires were processed using a computer program for statistical data processing - SPSS 13.0 for Windows.

The main research questions in the questionnaire "Young Specialist in the labor market: the needs of employers" include: 
- assessment of the situation related to the availability of personnel in the main profile of the organization (enterprise);

- information about hiring of youth representatives;

- the preferred level of training of young citizens when hiring;

- satisfaction with professional training of young specialists;

- highlighting the main problems of interaction between business and education in the current conditions of the region's development, etc.

\section{Results and discussion}

This study focuses on issues related to the needs of employers in the youth workforce for the organization and development of production.

Table 1 provides information on the scope of the organizations whose managers were interviewed.

Table 1. Distribution of respondents by organization activity area.

\begin{tabular}{|c|c|c|}
\hline Activity area & $\begin{array}{c}\text { Frequency } \\
\text { (number of organizations) }\end{array}$ & Valid percentage \\
\hline Industry & 215 & 10.7 \\
\hline Agriculture & 255 & 12.7 \\
\hline Transport, transportation & 168 & 8.4 \\
\hline Construction & 193 & 9.6 \\
\hline Information \\
Technologies
\end{tabular}

According to Table 1, the respondents in the structure of the sample population are as follows: $25.7 \%$ - representatives of the sphere of economics and finance, $15.5 \%$ - service sector, $12.7 \%$ - agriculture, etc.

The survey showed that half of the respondents were representatives of small businesses (47.4\%), the proportion of medium and large businesses is almost equal $(29.7 \%$ and $22.9 \%$, respectively).

Contingency table 2 (distribution of variables in order to determine the relationship between them) presents information about the scope of the surveyed organizations, taking into account the number of their employees. 
Table 2. Distribution of the number of respondents according to the organization activity area and the number of employees.

\begin{tabular}{|c|c|c|c|c|c|c|c|c|c|}
\hline \multirow[b]{2}{*}{$\begin{array}{l}\text { Number of employees } \\
\text { organizations } \\
\text { (enterprise) }\end{array}$} & \multicolumn{8}{|c|}{ Organization (enterprise) activity area } & \multirow[t]{2}{*}{ Total: } \\
\hline & 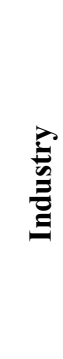 & & 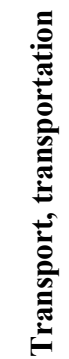 & 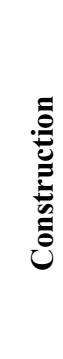 & 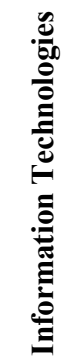 & 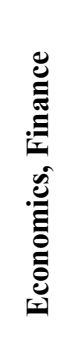 & 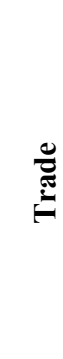 & 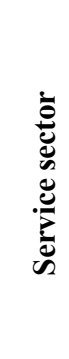 & \\
\hline Up to 100 people & 24 & 95 & 58 & 104 & 104 & 198 & 147 & 220 & 950 \\
\hline Up to 250 people & 56 & 84 & 110 & 33 & 40 & 201 & 0 & 71 & 595 \\
\hline Over 250 people & 135 & 76 & 0 & 56 & 36 & 116 & 19 & 20 & 458 \\
\hline Total: & 215 & 255 & 168 & 193 & 180 & 515 & 166 & 311 & 2003 \\
\hline
\end{tabular}

Based on the processed data we can conclude that:

- The sample of small organizations is represented by service organizations (23\%), economics and finance $(21 \%)$, trade $(15 \%)$, etc.;

- The share of medium-sized organizations (enterprises) is represented as follows: economics, finance (34\%), transport, transportation (18\%), agriculture (14\%), etc;

- Large business is represented by industry (29\%), economics and finance (25\%), agriculture (16\%), etc.

Table 3 presents the results of the survey on the respondents' assessment of the availability of human resources in the Republic in the main profile of the organization (enterprise).

Table 3. Distribution of the number of interviewed managers, who assessed the situation with the availability of staff, taking into account the main profile of organizations (enterprises).

\begin{tabular}{|c|c|c|c|c|}
\hline \multirow{2}{*}{$\begin{array}{c}\text { Organization activity } \\
\text { area }\end{array}$} & \multicolumn{3}{|c|}{$\begin{array}{c}\text { How would you assess the situation with the } \\
\text { availability of staff in the main profile of your } \\
\text { organization (enterprise) in the Republic? }\end{array}$} & \multirow{2}{*}{ Total: } \\
\cline { 2 - 4 } & Sufficient & Not sufficient & $\begin{array}{c}\text { Severe } \\
\text { shortage }\end{array}$ & \\
\hline Industry & 36 & 150 & 29 & 215 \\
\hline Agriculture & 98 & 66 & 91 & 255 \\
\hline Transport, transportation & 25 & 116 & 27 & 168 \\
\hline Construction & 100 & 85 & 8 & 193 \\
\hline Information Technologies & 25 & 68 & 87 & 180 \\
\hline Economics, Finance & 163 & 198 & 154 & 515 \\
\hline Trade & 32 & 58 & 76 & 166 \\
\hline
\end{tabular}


Continuation of table 3 .

\begin{tabular}{|c|c|c|c|c|} 
Service sector & 37 & 197 & 77 & 311 \\
\hline Total: & 516 & 938 & 549 & 2003 \\
\hline
\end{tabular}

According to the data of Table 3 we can conclude that $47 \%$ of respondents state that the necessary personnel (qualified specialists and workers) are insufficient for effective development of the Republic (economics, finance, service sector $-21 \%$, industry $-16 \%$, transport, transportation - $12 \%$, etc.); at that, $27 \%$ of heads of organizations (representatives) note that the region is in urgent need of qualified personnel: representatives of economics, finance (28\%), agriculture, technology sector - $16 \%$ respectively and others. In turn, some representatives of the sphere of economics, finance $(31 \%)$, construction, agriculture $(19 \%)$, etc. confidently note that the necessary personnel in the Republic is enough for its effective development.

Table 4 shows the answers to the same question, taking into account the number of employees of organizations (enterprises).

Table 4. Distribution of the number of interviewed managers who assessed the situation with the number of employees of organizations (enterprises).

\begin{tabular}{|c|c|c|c|c|}
\hline \multirow{2}{*}{$\begin{array}{c}\text { Number of } \\
\text { of employees } \\
\text { organizations } \\
\text { (enterprise) }\end{array}$} & \multicolumn{2}{|c|}{$\begin{array}{c}\text { How would you assess the situation with the } \\
\text { availability of staff in the main profile of your } \\
\text { organization (enterprise) in the Republic? }\end{array}$} & \multirow{2}{*}{ Total: } \\
\cline { 2 - 4 } & Sufficient & Not sufficient & $\begin{array}{c}\text { Severe } \\
\text { shortage }\end{array}$ & \\
\hline Up to 100 people & 310 & 378 & 262 & 950 \\
\hline Up to 250 people & 98 & 337 & 160 & 595 \\
\hline Over 250 people & 108 & 223 & 127 & 458 \\
\hline Total: & 516 & 938 & 549 & 2003 \\
\hline
\end{tabular}

Based on the responses to this question, it shows that $47 \%$ of respondents noted a lack of staff in the profile of the organization (enterprise), of which $40 \%$ are representatives of small businesses, 36\% - medium-sized businesses, 24\% - large businesses, respectively.

Table 5 provides relevant information for representatives of young people: multiple hiring of young professionals.

Table 5. Distribution of the number of interviewed managers on the basis of multiple hiring of young specialists, taking into account the main profile of organizations (enterprises).

\begin{tabular}{|c|c|c|c|c|c|}
\hline \multirow{2}{*}{$\begin{array}{c}\text { Organization activity } \\
\text { area }\end{array}$} & \multicolumn{3}{|c|}{ How often do you hire young specialists? } & \multirow{2}{*}{ Total: } \\
\cline { 2 - 5 } & $\begin{array}{c}\text { Every } \\
\text { year }\end{array}$ & $\begin{array}{c}\text { Once in } \mathbf{2 - 3} \\
\text { years }\end{array}$ & Very rarely & Not at all & \\
\hline Industry & 41 & 110 & 64 & 0 & 215 \\
\hline Agriculture & 65 & 8 & 120 & 62 & 255 \\
\hline $\begin{array}{c}\text { Transport, } \\
\text { transportation }\end{array}$ & 59 & 57 & 52 & 0 & 168 \\
\hline Construction & 68 & 80 & 45 & 0 & 193 \\
\hline $\begin{array}{c}\text { Information } \\
\text { Technologies }\end{array}$ & 36 & 85 & 59 & 0 & 180 \\
\hline Economics, Finance & 324 & 56 & 112 & 23 & 515 \\
\hline Trade & 69 & 37 & 33 & 27 & 166
\end{tabular}


Continuation of table 5 .

\begin{tabular}{|c|c|c|c|c|c|} 
Service sector & 144 & 123 & 44 & 0 & 311 \\
\hline Total: & 806 & 556 & 529 & 112 & 2003 \\
\hline
\end{tabular}

Considering the answers of respondents we can conclude that annually $40 \%$ of organizations employ young specialists, among which leading representatives of economics, finance $-40 \%$, services $-18 \%$, trade $-8 \%$, etc.; once in $2-3$ years organizations of services $-22 \%$, industry $-19 \%$, information technology $-15 \%$, etc. are interested in employing young specialists; very rarely do several representatives of agriculture $-22 \%$, certain representatives of economics, finance $-21 \%$, etc. $55 \%$ of agricultural, $24 \%$ of trade and $20 \%$ of economics and finance organizations avoid hiring of youth.

Table 6 provides information based on the question discussed in the previous table, taking into account the number of employees of the organizations (enterprises) interviewed.

Table 6. Distribution of the number of interviewed managers on the basis of multiple hiring of young specialists, taking into account the number of employees of organizations (enterprises).

\begin{tabular}{|c|c|c|c|c|c|}
\hline \multirow{2}{*}{$\begin{array}{c}\text { Number of } \\
\text { of employees } \\
\text { organizations } \\
\text { (enterprise) }\end{array}$} & \multicolumn{3}{|c|}{ How often do you hire young specialists? } & \multirow{2}{*}{ Total: } \\
\cline { 2 - 5 } & Every year & $\begin{array}{c}\text { Once in 2-3 } \\
\text { years }\end{array}$ & $\begin{array}{c}\text { Very } \\
\text { rarely }\end{array}$ & Not at all & \\
\hline Up to 100 people & 333 & 338 & 244 & 35 & 950 \\
\hline Up to 250 people & 324 & 76 & 158 & 37 & 595 \\
\hline Over 250 people & 149 & 142 & 127 & 40 & 458 \\
\hline Total: & 806 & 556 & 529 & 112 & 2003 \\
\hline
\end{tabular}

The survey showed that representatives of small and medium business are more interested in hiring young specialists every year $-41 \%$ and $40 \%$ respectively; once in $2-3$ years representatives of the same small business employ young specialists $(60 \%)$, large organizations of the Republic - 25\%; small (46\%), medium (30\%) and large organizations (24\%) employ young specialists very rarely; large, medium and small organizations do not employ young specialists at all $-35 \%, 24 \%$ and $31 \%$ respectively.

When answering the question: "What do you pay attention at first when hiring young specialists in your organization (enterprise)?", the answers, taking into account the activity area and the number of employees of organizations (enterprises), were distributed as follows: $35 \%$ of respondents, including representatives of small and medium-sized businesses of economics, finance, services, transport, transportation, industry, etc. pay attention to the compliance of education with the requirements of the vacant position; $24 \%$ of respondents who are small and medium-sized organizations of information technology, industry, economics, finance focus on professional training; $67 \%$ of respondents in economics, finance (32\%), services (16\%) and others consider, primarily, personal and business qualities, general abilities. Only $10 \%$ of respondents pay attention to the appearance of the applicant for the job.

As for the answer to the next question: "What level of training do you prefer young specialists when hiring?", the respondents noted the following: $58 \%$ of the total number of respondents are interested in qualified workers and specialists with secondary education, among which $40 \%$ are large, $23 \%$ - medium, 37\% - small organizations in services, industry, agriculture, construction and others; large (24\%), medium (16\%) and small organizations (32\%) need bachelors and masters in the following fields of activity: economics, finance, trade, services, industry, etc.; for $10 \%$ of respondents, in particular 
small organizations in the service sector, industry, etc., the level of training of young professionals does not matter at all.

In the course of the survey, the information concerning the respondents' satisfaction with the professional training of young specialists after graduation from the educational organization was investigated, taking into account the organization activity area (Table 7).

Table 7. Data on the degree of satisfaction with professional training of young specialists, taking into account the main profile of organizations (enterprises).

\begin{tabular}{|c|c|c|c|c|c|}
\hline \multirow{2}{*}{$\begin{array}{c}\text { Organization activity } \\
\text { area }\end{array}$} & \multicolumn{6}{|c|}{$\begin{array}{c}\text { Are you satisfied with the professional training of } \\
\text { young specialists after the educational institution? }\end{array}$} & \multirow{2}{*}{ Total: } \\
\cline { 2 - 6 } & Yes & Not & Partially & Hard to answer & \\
\hline Industry & 12 & 0 & 179 & 24 & 215 \\
\hline Agriculture & 69 & 45 & 114 & 27 & 255 \\
\hline Transport, transportation & 51 & 27 & 90 & 0 & 168 \\
\hline Construction & 0 & 69 & 124 & 0 & 193 \\
\hline Information Technologies & 32 & 44 & 104 & 0 & 180 \\
\hline Economics, Finance & 60 & 183 & 237 & 35 & 515 \\
\hline Trade & 4 & 69 & 93 & 0 & 166 \\
\hline Service sector & 27 & 73 & 179 & 32 & 311 \\
\hline Total: & 255 & 510 & 1120 & 118 & 2003 \\
\hline
\end{tabular}

The data in the table show that:

- 56\% of the respondents are not completely satisfied with the professional training of specialists: economics and finance (21\%), service sector, industry (16\%), construction $(11 \%)$, agriculture (10\%), etc;

- $25 \%$ of respondents are not satisfied with the training of graduates at all: economics, finance $(35 \%)$, services (14\%), construction, trade (13\%), agriculture ( $9 \%)$, etc;

- $13 \%$ of respondents are satisfied with the training, including representatives of agriculture (27\%), economics, finance (23\%), transport and shipping (20\%), etc;

- $6 \%$ of respondents found it difficult to answer the question.

Table 8 shows the answers of respondents to the same question, taking into account the number of employees of organizations (enterprises).

Table 8. Data on the degree of satisfaction with professional training of young specialists, taking into account the number of employees of organizations (enterprises).

\begin{tabular}{|c|c|c|c|c|c|}
\hline \multirow{2}{*}{$\begin{array}{c}\text { Number of } \\
\text { of employees } \\
\text { organizations } \\
\text { (enterprise) }\end{array}$} & \multicolumn{3}{|c|}{$\begin{array}{c}\text { Are you satisfied with the professional training of } \\
\text { young specialists after the educational institution? }\end{array}$} & \multirow{2}{*}{ Total: } \\
\cline { 2 - 5 } & Yes & Not & Partially & Hard to answer & \\
\hline Up to 100 people & 90 & 345 & 495 & 20 & 950 \\
\hline Up to 250 people & 125 & 97 & 322 & 51 & 595 \\
\hline
\end{tabular}


Continuation of table 8.

\begin{tabular}{|c|c|c|c|c|c|}
\hline Over 250 people & 40 & 68 & 303 & 47 & 458 \\
\hline Total: & 255 & 510 & 1120 & 118 & 2003 \\
\hline
\end{tabular}

The survey showed that:

- $44 \%$ of respondents from small businesses, $29 \%$ and $23 \%$ from medium and large businesses, respectively, are not completely satisfied with the training of graduates;

- $67 \%$ of managers of small, medium-sized (20\%) and 13\% of large organizations are not at all satisfied with the training;

- $49 \%$ of medium-sized businesses are completely satisfied with the training.

The same $6 \%$ of respondents found it difficult to answer the question.

Figure 1 highlights the main reasons why employers refuse to hire young citizens.

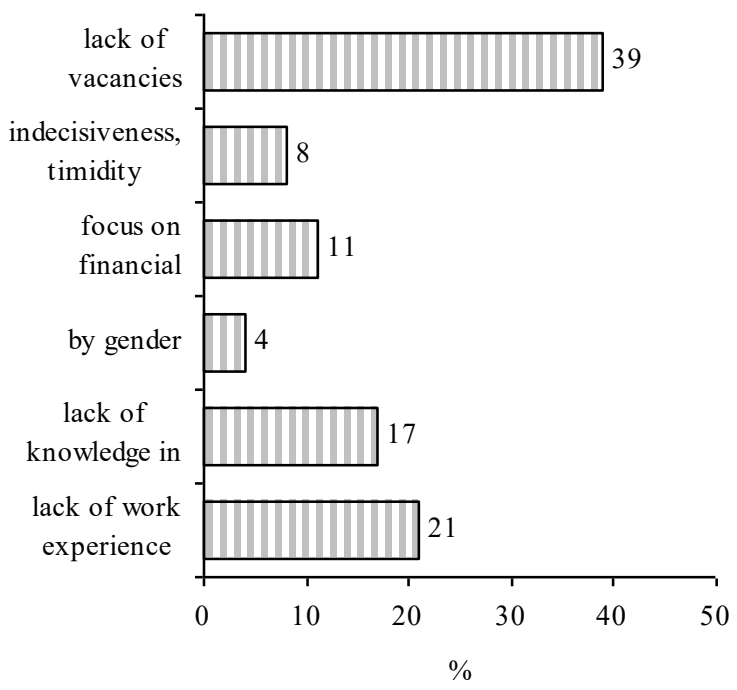

Fig. 1. The main reasons why employers refuse to hire young citizens, $\%$.

The most important reasons for employers to refuse to hire young people are lack of vacancies (39\%); lack of work experience $(21 \%)$; lack of knowledge in the field of training $(17 \%)$, etc.

\section{Conclusion}

Based on the study we can conclude that in modern conditions there is a significant need for the development of labor potential of young people and its use in the interests of innovative development of the Republic, which can be realized through the following activities:

- strengthening the activities of regional authorities to promote the employment of young people, in particular graduates of educational institutions;

- taking into account the age and gender composition of working specialists in certain areas for possible replacement;

- strengthening of interaction between the labor market and the market of educational services, which is associated, first of all, with the need to conduct a systematic analysis of 
supply and demand in the labor market of young people; development and implementation of a set of measures to improve the structure of in-demand areas of training implemented by educational institutions of higher and secondary vocational education;

- reducing the number of specialists in training areas and specialties for which employment is becoming problematic;

- creation of the most favorable conditions on the part of the national authorities for the development of entrepreneurial activity (in particular, small business), which would significantly increase the number of jobs and reduce the tension in the labor market;

- use of economic incentives capable of increasing the interest of organizations in employing young people of all age groups, their professional training, professional development and retraining;

- improvement of the system of situation monitoring and detailed modeling of processes for the development and implementation of staffing needs in the labor market, etc.

Professional-qualification imbalance in the labor market of the Republic is one of the serious problems that reduce the efficiency of social production, first, because of the mismatch between the qualifications of workers and the basic requirements of employers, and second, because of the staff shortage in a number of professions and training areas (75\% of jobs offered by employers in the labor market are for the worker's professions seekers, while the share of training is only $33 \%$ of the total number of graduates in region). Therefore, the task of reducing this imbalance is currently one of the most significant for the development of the Republic of Crimea.

\section{References}

1. N. Simchenko, E. Polishchuk, Institutional practices of employment regulation in the Republic of Crimea, Drukerov. Vestnik, 2, 263-271 (2016)

2. S. Tsohla, E. Polishchcuk, The market of educational services, demand and supply of labor (Arial, Simferopol, 2013)

3. V. Bylkov, Legitimate transformation of demand in the Labor market, Izvestiya of Irkutsk State Economics Academy, 3(25), 416-425 (2015). DOI: 10.17150/1993-3541

4. V. Bylkov, Characteeristic Features of Demand Development in Labour Market, Journal of New Economy, 5(67), 88-99 (2016)

5. E. Budnik, E. Bavykina, The quality assessment of the young specialists labor market, Human Progress, 4(4) (2018)

6. N. Prokopov, S. Antonyuk, S. Ivanov, D. Ivanova, Practices of successful employment of the youth, Higher Education in Russia, 6(213), 88-95 (2017)

7. M. Khokhlova, Competencies of a competitive young professional: opinion of employers and graduates, Telescop, 2(104), 26-31 (2014)

8. B. Meskhi, V. Filonenko, L. Skachkova, J. Filonenko, Problems and paradoxes of the employmeny of students in the assessments of employers (based on the results of a sociological study), The Authority, 10, 83-90 (2017)

9. P. Protsch, Employers' recruitment contexts and hiring preferences in the German youth labor market, Res. in Soc. Strat. and Mobil., 73 (2021). DOI: https://doi.org/10.1016/j.rssm.2021.100608

10. Y. He, P. Xiujian, H. Xu, Overeducation, market recognition, and effective labour supply, China Econ. Review, 59, 101384 (2020). DOI: https://doi.org/10.1016/j.chieco.2019.101384 
11. L. Patel, L. Graham, G. Chowa, Evidence of non-economic indicators as markers of success for youth in youth employability programs: Insights from a South African study, Childr. and Youth Serv. Review, 118 (2020). DOI: https://doi.org/10.1016/j.childyouth.2020.105404

12. J. Kolesnikova, A. Kamasheva, A. Fakhrutdinova, Higher Education Demands of The Labor Market, Proc.- Soc. and Behav. Scienc., 191, 1183-1186 (2015). DOI: 10.1016/j.sbspro.2015.04.446

13. B. Gontkovičová, B. Mihalčová, M. Pružinský, Youth unemployment - current trend in the labour market? Proced. Econom. and Finan., 23, 1680-1685 (2015). DOI: 10.1016/S2212-5671(15)00554-7

14. J. Kluve, S. Puerto, D. Robalino, J. Romero, F. Rother, J. Stöterau, F. Weidenkaff, M. Witte, Do youth employment programs improve labor market outcomes? A quantitative review, World Develop, 114, 237-253 (2019). DOI: https://doi.org/10.1016/j.worlddev.2018.10.004

15. L. Refrigeri, G. Aleandri, Educational policies and youth unemployment, Proc. - Soc. and Behav. Scien., 93, 1263-1268 (2013). DOI: 10.1016/j.sbspro.2013.10.026 